\title{
FAMILY POLICY IN THE STRATEGIC PLANNING OF RURAL MUNICIPALITIES IN THE CZECH REPUBLIC
}

Helena Hudečková, Jakub Husák, Rudolfina Voleská1

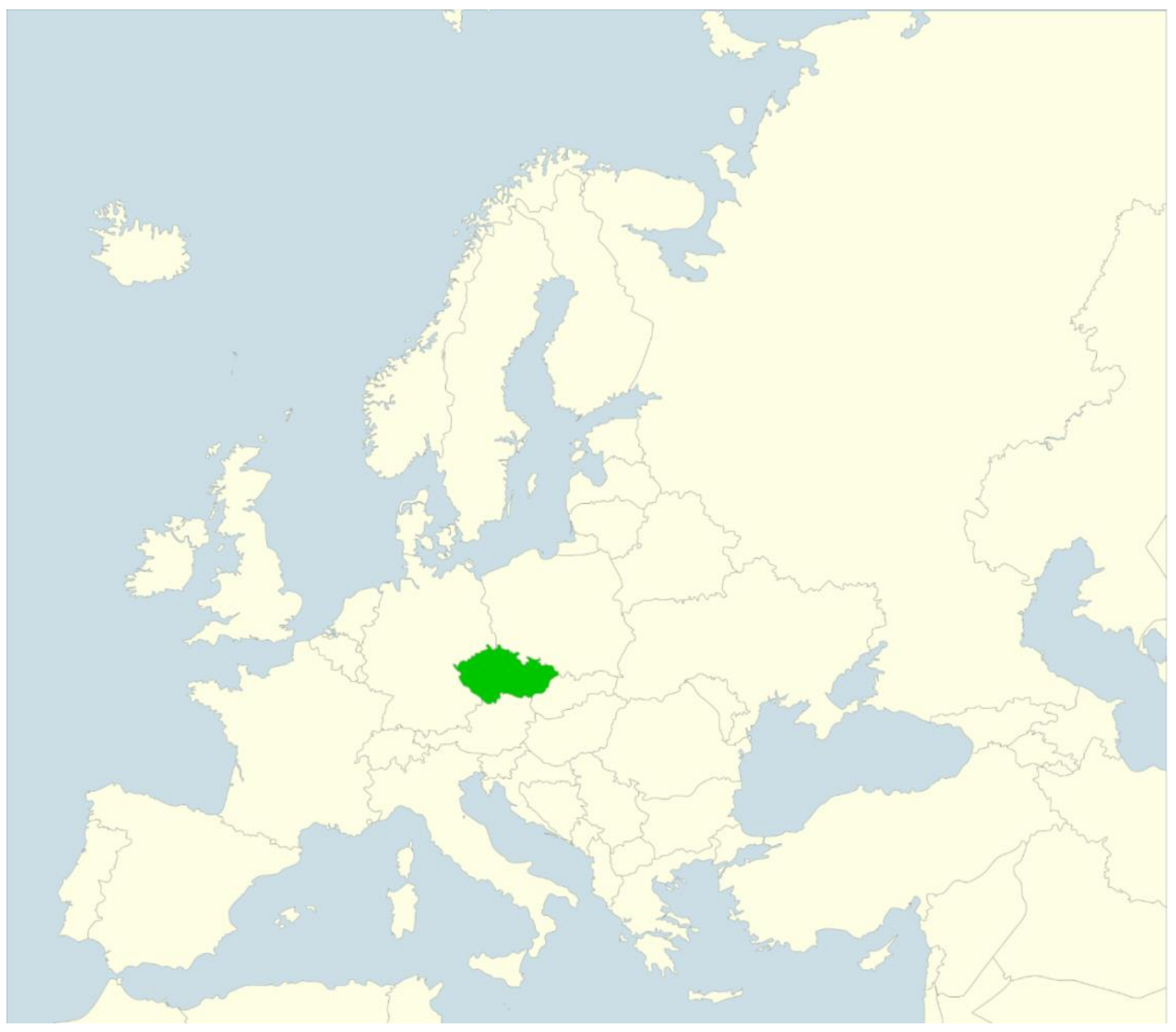

1 Doc. Mgr. Helena Hudečková, CSc., e-mail: hudeckova@pef.czu.cz; Ing. Jakub Husák, Ph.D., ORCID: 0000-00017166-9252, e-mail: husak@pef.czu.cz; Mgr. et Mgr. Rudolfina Voleská, e-mail: voleska@pef.czu.cz, Czech University of Life Sciences Prague 


\begin{abstract}
The paper is focused on Family Policy of rural municipalities. National strategic documents, documents intended for implementation of Family Policy at regional and local levels and local plans/conceptions for Family Policy within municipalities of up to 5,000 inhabitants are analysed. Special attention is paid to the competition: "Familyfriendly Community". Results of the analysis show that this competition does not fulfil its mission, despite the favourable environment for Family Policy within rural municipalities. The results of the study in accordance with generally prevailing opinion show, that it is not efficient to elaborate conceptions of Family Policy within such small municipalities.
\end{abstract}

Keywords: Family-friendly Community, Family Policy, rural municipalities, strategic planning

\begin{abstract}
Abstrakt: Článek se zaměřuje na rodinnou politiku venkovských obcí. Metodou analýzy dokumentů zkoumá príslušné národní strategické dokumenty, dokumenty k implementaci na regionální a lokální úrovni a vyhledané lokální plány/koncepce rodinné politiky obcí do 5000 obyvatel. Zvláštní pozornost věnuje iniciační soutěži „Obec přátelská rodině“. Výsledky analýzy dokumentují, že tato soutěž neplní své poslání, i když ve venkovských obcích je pro rodinnou politiku vytvořené prríznivé prostředí. Výsledky studie se přiklánějí k mínění, že zpracovávat specifické koncepce pouze pro rodinnou politiku není u takto malých obcí efektivní.
\end{abstract}

Klíčová slova: Obec přátelská rodině, rodinná politika, venkovské obce, strategické plánování

\title{
1. Introduction
}

The paper is focused on intersection of Social and Regional Policy within its current eclectic period (Blažek \& Uhlír, 2011). From this perspective, the paper is particularly focused on Family Policy as a part of Social Policy. The research intention of the authors is to examine if local Family Policy in the Czech Republic is based on systematically elaborated document according to recommendations of decision-making bodies (see below). The specific attention is paid to rural areas while we draw on the fact that legislation in the Czech Republic regulates only basic measures within the system of the social security of families - state social support benefits and material need benefits.

The strategic document: "National Conception of Family Policy" was adopted in 2005. It was followed in 2008 by standards at the level of recommendations, which elaborate the conception at regional and municipal levels. However, the authors of the paper consider these documents as still having a rather proclamative character. In particular, considering rural municipalities, if they implement Family Policy, the effects of the above-mentioned documents are rather unsystematic.

This could be the result that conceptualisation of Family Policy is rather broad and varies between the states. In general, Family Policy includes set of measures that targeted various aspects of family, which form specific dimensions of Family Policy. These dimensions usually include maternity protection, parental-leave policies, childcare services, child benefits, gender relations in families, housing and transportation conditions for families and harmonisation of labour and family life (Neyer, 2003). However, not all above-mentioned dimensions are designated to local level. The dimensions that are primarily implemented by local government and also dimensions connected to regional policy will be discussed throughout the paper (see Result section especially analysis of the $2^{\text {nd }}$ level of documents).

Considering the Czech Family Policy, it was significantly changed after 1989 towards broader social welfare concerns. Special attention was paid on parental leave policy. The Czech Republic also supports the EU agenda with regard to Family Policy and gender equality after accession to the EU. Current Family Policy combines long period of parental leave and a low availability of early childcare, which is assigned especially to municipal administration (Frejka \& Basten, 2016). 
Authors discussing models of Family Policy suitable for the Czech Republic incline towards the conservative model. However, their discussion was not reflected within the first version (2005) of the National Conception of Family Policy (Belling, 2005 and 2010; Matějková \& Paloncyová, 2004; Munková, 2005; Jirková, 2009; Kocourková, 2009; Kučera, 2009). This issue is also reflected in the Czech Republic within the theoretically focused papers (Možný, 2006; Mlčoch, 2009 and 2014; Smutek, 2015) which reflect the European context (Wingen, 1997; EspingAndersen, 2009; Kuronen, 2010; Thévenon, 2011). The revised version of the National Conception of Family Policy (2016) already used a model practised elsewhere in Europe as the structure.

In this context, the shortage of conceptualisation of Family Policy in the Czech Republic is the absence of clear definition of competences entrusted by law for the independent competences of municipalities with regard to Family Policy. This is the reason for the fact that various activities and measures of pro-Family Policy are implemented in rural municipalities in the Czech Republic at different levels, corresponding to the interests of municipal self-government in this part of Social Policy.

Since 2008, it has been possible to see the specific efforts of the national government to support municipal Family Policy through the organisation of a competition: "Family-friendly Community". Within the framework of this competition, municipalities which are active in Family Policy are awarded. These municipalities are used as examples of good practice. However, current experience (see below) acknowledges that repercussions of the competition are still minimal. In this context, it cannot be assumed that the impact of the competition to activate municipalities with regard to Family Policy is full-scale. However, the main mission of the Competition is to promote pro-family environment within the Czech municipalities and stimulate its development (MLSA, 2018).

The authors of the paper consider that systematically implemented local Family Policy stems mainly from awareness of the fact that the created set of measures (considering the activities for particular target groups - children and youth, families with children and seniors) should be consistent with the municipal development strategy. These measures should also be planned in the long term with regard to the structure of local families. It would be appropriate also to incorporate into the set of measures the cycle of family life and corresponding needs within the areas of the formation of the family background, family scale, raising of children, care of the elderly and harmonisation of family and working life. Finally, an important issue is also ensuring the institutional conditions (legislative, financial and organisational) to meet the aforementioned set of pro-family measures at the municipal level. In accordance with abovementioned facts, we suppose that municipalities, under conditions of the extension of their competencies, could have higher potential to resolve some important tasks of Family Policy better than the national government.

The paper consists of the selected results of the first part of the research carried out within the project: "School as Actor of Community-Led Local Development (Intersection of Regional, Educational and Family Policies)". The main aim of the paper is to research and evaluate effort to support Family Policy at the level of rural municipalities through organising of competition "Family-friendly Community".

\section{Theoretical Background}

Whereas we focus on question, which dimensions of Family Policy could be implemented at municipal (local) level better than at national level (when setting an appropriate institutional framework), this issue belongs to the concept of neo-endogenous rural development (Ray, 2000; Shucksmith, 2010). This model of rural development consists of the principal usage and valorisation of the endogenous potential of rural space (Lowe, 2000). Attention is also paid to diversity of developmental resources and the broadest possible variability in their utilisation (Ward, 2005; Shucksmith, 2010).

Considering the perspectives of Social Policy, it is necessary to mention the reconceptualisation of the Welfare State (Arts \& Gelissen, 2002) while it is assumed the limiting role of the national government as provider of public services and strengthening the principle subsidiarity by 
a delegation of responsibility for the social autonomy of individuals at a lower level of governance (Drucker, 2004).

Another concept that forms the theoretical background of the paper (and belongs in the sphere of social policy) is the concept of social exclusion and the complementary concept of social inclusion. Both concepts have been mentioned within scientific discourse and Social Policy documents since the 1990s. Both concepts replace and extend the concept of poverty (Shusksmith, 2012). While the concept of poverty emphasises the economic dimension, the concepts of social exclusion and inclusion also emphasise the cultural and social aspects of social life. Efforts at social inclusion express an interest in full political and social citizenship (Atkinson, 2000). Considering Social Policy documents on social exclusion and inclusion, among the groups also mentioned that are threatened by social exclusion are children and youth, families with children, and seniors. These groups are considered as objects of Family Policy.

At a lower level of generality, it is necessary to mention the LEADER approach, which has been implemented into the praxis of rural development since the beginning of $1990^{\mathrm{s}}$ and 10 years later in the Czech Republic ${ }^{2}$. This approach respects all the above-mentioned theoretical concepts. Experience with this approach was summarised for the purpose of the praxis of the Rural Development Policy in the strategic document called "National Strategic Plan LEADER 2014+" (NNLAG 2011) and supplementary to the document called "Community-led local development in the Czech Republic" (NNLAG 2012).

Community-led local development (CLLD) is also a key term of the Agenda for a reformed cohesion policy, which is also known as the "Barca Report" (Barca, 2009). The development thus named emphasises the basis of local needs and the integration of local potential, which are used to resolve needs by joining the forces of local actors. The theoretical background for CLLD is formed by institutional regional development theories (Hudson, 2007; Morgan, 2007; Amin \& Thrift, 1995), especially by concepts which emphasise the elements of the sociocultural environment of locality (mainly ties in the network of contacts and embeddedness in the locality) as developmental resources (Granovetter, 1985; Atterton, 2007).

The above-mentioned concepts support the assumption of the authors of this paper that municipalities (when improving institutional conditions) are able to resolve Family Policy issues better than the national government. We analyse the current state of the creation and realisation of the local strategy of Family Policy. The intention is to evaluate the desirable changes within the institutional framework to support the development of local Family Policy.

\section{Methodology}

The paper presents results of the first part of the research, focused on analysis of specific documents devoted to local Family Policy realised within municipalities of up to 5,000 inhabitants in the Czech Republic.

OECD methodology, which is used for international comparison of living conditions and developmental trends at municipal level and which is based on a population density criterion, was used for definition of rural municipalities. With regard to the purpose of our research, this criterion was combined with a criterion of the number of inhabitants at the level of 5,000. This is an often used criterion for socio-geographic and sociological research of rural areas in the Czech Republic.

The research sample consists of all the municipalities of up to 5,000 inhabitants, which won the "Family-friendly Community" competition (hereinafter Competition). Most of them have elaborated a strategic document for the development of local Family Policy. ${ }^{3}$

As is apparent from Figure 1, strategic documents of only some of these municipalities were possible to be analysed, because we managed to obtain these documents (the documents were

\footnotetext{
${ }^{2}$ One of the authors of the paper is pursuing the issue of the implementation of the LEADER approach in the praxis of rural development from the beginning of its application in the Czech Republic, as is evidenced by numerous publications (e.g. publications by Hudečková and Lošták in Agricultural Economics between 2003 and 2011).

${ }^{3}$ This fact was verified by the authors of the paper by searching in publicly available sources or by questioning the particular municipalities.
} 
publicly available, where annexes to the Application for the Competition, or the documents were provided by municipalities on request). This does not mean that other municipalities of up to 5,000 inhabitants do not realise particular activities within local Family Policy. It can be assumed that rural municipalities realise these activities as a part of their development plans. However, there is usually a missing particular document systematically elaborated to the extent that it could be compared with recommendations of the Ministry of Labour and Social Affairs from the year 2008. However, it is not possible to verify this fact because 5,984 municipalities of up to 5,000 inhabitants in the Czech Republic exist. It is also necessary to mention that documents about the Competition were provided by the Ministry of Labour and Social Affairs after several reminders and are incomplete (without the 2011 and 2012 years).

Table 1 shows Regions (NUTS 3), which are sorted according to the frequency of occurrence of municipalities of up to 5,000 inhabitants which won the Competition. Municipalities of up to 5,000 inhabitants from other Regions (Karlovy Vary, Hradec Králové, Pilsen and Zlín) did not win between the years $2008-2010$ and $2013-2017$.

Tab 1. Overview of municipalities of up to 5,000 inhabitants within the Czech Republic, which won the Competition and elaborated local strategy documents on Family Policy.

\begin{tabular}{|c|c|c|c|c|c|}
\hline \multirow{2}{*}{$\begin{array}{l}\text { Region } \\
\text { (NUTS 3) }\end{array}$} & \multirow{2}{*}{$\begin{array}{l}\text { Municipality } \\
\text { (LAU 2) }\end{array}$} & \multirow[b]{2}{*}{ Legal status } & \multicolumn{2}{|c|}{ Population } & \multirow[b]{2}{*}{ Note } \\
\hline & & & Number & $\begin{array}{l}\text { Density } \\
/ \mathbf{k m}^{2}\end{array}$ & \\
\hline \multirow[t]{4}{*}{$\begin{array}{l}\text { Central } \\
\text { Bohemia }\end{array}$} & $\begin{array}{l}\text { Dolní } \\
\text { Břežany }\end{array}$ & Rural municipality & 3896 & 365 & \\
\hline & Pyšely & Town & 1905 & 149 & $A, D$ \\
\hline & Kouřim & Town & 1882 & 131 & $A, D$ \\
\hline & Ledčice & Rural municipality & 628 & 57 & $A, D$ \\
\hline \multirow{3}{*}{$\begin{array}{l}\text { South } \\
\text { Bohemia }\end{array}$} & Borovany & Town & 4133 & 98 & $A, D$ \\
\hline & Nové Hrady & Town & 2527 & 32 & $A, D$ \\
\hline & Dub & Small town & 380 & 26 & $A, D$ \\
\hline \multirow{3}{*}{$\begin{array}{l}\text { Moravian- } \\
\text { Silesian }\end{array}$} & Bolatice & Rural municipality & 4443 & 336 & $A, D$ \\
\hline & Otice & Rural municipality & 1421 & 197 & $A, D$ \\
\hline & Darkovice & Rural municipality & 1367 & 266 & \\
\hline \multirow{3}{*}{$\begin{array}{l}\text { South } \\
\text { Moravia }\end{array}$} & Vacenovice & Rural municipality & 2187 & 149 & \\
\hline & Lysice & Small town & 1921 & 179 & $A, D$ \\
\hline & Velatice & Rural municipality & 722 & 319 & \\
\hline \multirow[t]{2}{*}{ Vysocina } & Hrotovice & Town & 1770 & 83 & $\mathrm{D}$ \\
\hline & Věžnice & Rural municipality & 409 & 29 & $A, D$ \\
\hline \multirow[t]{2}{*}{ Olomouc } & Vrchoslavice & Rural municipality & 610 & 180 & \\
\hline & Babice & Rural municipality & 463 & 78 & \\
\hline Liberec & Dubá & Town & 1716 & 28 & $A, D$ \\
\hline Usti & Krásná Lípa & Town & 3478 & 111 & \\
\hline Pardubice & Chrast & Rural municipality & 3129 & 175 & $A, D$ \\
\hline
\end{tabular}

Note: $\mathrm{D}=$ verification of Family Policy strategy document existence; $\mathrm{A}=$ document was analysed, to meet the content and formal needs for comparative analysis and was acquired for this purpose

The research sample thus consists of 20 municipalities, out of which 8 do not meet the criteria of population density of up to 150 inhabitants $/ \mathrm{km}^{2}$. Twelve of these municipalities were chosen for a narrower selection of municipalities whose local document - "Development Plan of Family Policy or Conception of Family Policy" - could be subjected to detailed analysis.

Documents on Family Policy at central (hereinafter the $1^{\text {st }}$ level of documents) and local (hereinafter the $2^{\text {nd }}$ level of documents) levels were subjects of the first part of the research using secondary analysis. The first document for analysis was the National Conception of Family Policy (hereinafter Conception), which was elaborated by the Ministry of Labour and Social Affairs in 2005 and revised in 2016 (MLSA 2005 and 2016). The main perspective of the analysis was the content shift between the base year of implementation and the year of revision of 
the Conception. Key attention was paid to systematicity (content, complexity and coherence of particular support areas of families and specific family situations), logic and coherence of objectives and specific measures, accuracy of liability determination and terms for the realisation of the aims and measures and clarity of the text.

Another analysed document was a follow-on norm, whose mission is to provide methodological recommendations for the elaboration of strategic documents on Family Policy at regional and municipal levels. ${ }^{4}$ The main perspective of the analysis was focused on the same categories as the above-mentioned Conception. The other important categories of analysis of this document were institutionalisation (legal support, division of competences at vertical level and financial support), actorship (the role of actors of Family Policy at regional and local levels) and methodological clarity (implementation procedures of documents on Family Policy at regional and local levels).

The last sets of analysed documents at the central level are documents about the process of the Competition (2008-2017). This set is not complete, but consists of relevant and comparable data $^{5}$ about the development of participation of municipalities within the Competition and conditions for participation. From the analysis, based on indicators of participation and winners in the Competition, we deduce whether the Competition fulfils the main mission, which declares itself - to motivate and promote the development of Family Policy at municipal level. Specific attention is also paid to the question of whether the success rate of these municipalities in the Competition corresponds/does not correspond to their repeated participation.

The results of the $1^{\text {st }}$ level of documents form the context for the analysis of the $2^{\text {nd }}$ level of documents. Twelve local documents from the municipalities up to 5,000 inhabitants are subjected to the analysis (see Figure 1). Multi-criterial typology of pro-family activities were created by the authors of the paper for the purpose of comparison of recommendations from the national level and locally elaborated documents supporting systematic realisation of pro-family activities. The typology is designed according to content/focus of activities, target groups (children and youth, families with children, seniors and others), type of activities (direct and indirect services, direct support by the use of local sources, activities with regard to quality of life and other accompanying activities), sources of financial support (municipal and supramunicipal), network of local cooperating actors and network of external contacts for the exchange of experience in the realisation of municipal Family Policy. The typology is used as a structure of categories and their properties for the analysis of Development Plans of Family Policy or Conceptions of Family Policy at the municipal level. This approach, according to the authors, allows to evaluate the $2^{\text {nd }}$ level of documents from the perspectives of their relation to the $1^{\text {st }}$ level of documents.

\footnotetext{
4 This document in particular, called "Family Policy at Regional and Municipal Levels - Methodological Recommendation of Ministry of Labour and Social Affairs of the Czech Republic" (MLSA, 2008) is evidence of the intermingling of Regional and Social Policy (and particularly also of Family Policy). This document, as methodological recommendation, is not of an obligatory character.

5 Part of the data was adjusted for the needs of time series analysis, due to the changes in categorisation of municipalities according to their size. I. category consists in 2008 municipalities up to 500 inhabitants, II. category municipalities between 501 and 3,000 inhabitants, III. category municipalities between 3,001 and 10,000 inhabitants, IV. category municipalities between 10,001 and 50,000 inhabitants and V. category municipalities with more than 50,000 inhabitants. Categorisation was changed in 2010 - I. category consists municipalities up to 500 inhabitants, II. category municipalities between 501 and 2,000 inhabitants, III. category municipalities between 2,001 and 5,000 inhabitants, IV. category municipalities between 5,001 and 10,000 inhabitants, V. category municipalities between 10,001 and 50,000 inhabitants and VI. category municipalities with more than 50,000 inhabitants. Categorization has stabilized since 2011 - I. category consists of municipalities up to 1,000 inhabitants, II. category municipalities between 1,001 and 3,000 inhabitants, III. category municipalities between 3,001 and 10,000 inhabitants, IV. category municipalities between 10,001 and 50,000 inhabitants and V. category municipalities with more than 50,000 inhabitants. The research consists of municipal categories I, II, and partly III, which often have changed the most often. Also, participation of municipalities in the researched categories were the most changeable - e.g. within the I. category participated in 2017 only 1 municipality while in 200851 municipalities participated, between these years, 14 municipalities participated in 2010, 3 municipalities in 2013, 4 municipalities in 2014 and 11 municipalities in 2015.
} 


\section{Results}

\section{The $1^{\text {st }}$ level of documents \\ Changes of Conception of Family Policy in the Czech Republic}

A comparison of the content and form of the original Conception of 2005 and its revised version in 2016 infer that there exists a shift, both in the contextual and formal aspects of the text. The text of the revised version is clearer and more comprehensive, despite being briefer.

Revised version of the Conception directly states that it is dealing with the shortcoming that, at the beginning of 21 st century, no elaborated model of Family Policy existed in the Czech Republic to correspond to some European models ${ }^{6}$. Thus, the way of conceptualisation of Family Policy was not clearly or systematically indicated. These facts, according to the authors, explain the descriptiveness and incoherence of the specific measures which should have been implemented with regard to Family Policy after 2000. Therefore, according to the authors, the Conception remained inoperative, despite the elaborated analysis of the current state of Family Policy (with the general part of the Conception) and the formulated aims and principles of their implementation. A specific part of the Conception consists of a division into particular sections of Family Policy - support of parenthood and family cohesion, financial support of family and housing, services for families, compatibility of professional and family roles, family and educational system, family and healthcare system, families with specific needs, support of families at the level of Regions (NUTS 3) and municipalities (LAU 2), and general measures for Family Policy support. The specific aims, particular measures and tasks, which were assigned to all the aforementioned sections of Family Policy, were also formulated. However, specific responsibilities and deadlines for implementation were formulated only vaguely and in general. Responsibility was divided among several ministries in all cases. In addition, particular specifications which should have been a guide for supervision, were, according to the authors, not sufficient.

The revised Conception analyses the current needs of families more systematically. The needs are divided into key sections - public services, flexible forms of employment, financial support, family care appraisal and free choice of reproduction. The analysis shows that this version of the Conception represents quite a sophisticated and comprehensive system of measures to increase the quality of life of families. The revised Conception consists of all the necessary key sections, in which the state support for families is important. The system of measures is elaborated with specifications of the responsibilities and could be used for the supervision of the realisation of the Conception. This version emphasises that the Czech Republic is lagging behind in comparison with trends within other OECD states with regard to expenditure for family support. The revised Conception also highlights the fact that a complex Act on family support in the Czech Republic is absent. The authors assume that the new general Act on family support could contribute to greater interconnection of Social Policy with other public policies (e.g. Regional Policy, Education Policy). It could also contribute to greater interconnection of particular parts of Social Policy themselves (especially Family Policy, Housing Policy and Employment Policy). Because the revised Conception is a strategic document with a presumed validity of five years for further revision, the aforementioned shortcomings could hinder realisation of Family Policy at national, regional and local levels. For the purpose of our research, linkage with Regional Policy is particularly important. This linkage is visible when considering another document at the central level, which is analysed below.

\section{Family Policy at the regional (NUTS 3) and municipal (LAU 2) levels}

This document has the character of a methodological Recommendation and follows up on the original Conception. The document (hereinafter Recommendation) was elaborated by the Ministry of Labour and Social Affairs of the Czech Republic in 2008. The Introduction and first part of the document have the aim of expressing relations to the Conception. According to

\footnotetext{
6 These are in particular the 4 classic Europeans models: conservative (Germany, Austria, Poland, Slovakia); socialdemocratic (Scandinavian states); liberal (Great Britain); combined (France, Luxemburg), which stem from EspingAndersen's typology. These are also adopted by Czech authors (Munková, 2005; Belling, 2010).
} 
the authors, the shortcoming of this document is the fact that introductory part emphasizes necessity of social protection of all developmental stages of families, but the proposed measures and tasks are addressed, almost without exception, to families with children. The other stages of families are neglected. Another important fact provided by the Recommendation is information about the institutionalisation of Family Policy. The Ministry of Labour and Social Affairs of the Czech Republic is only mentioned at the central level. However, this Ministry does not have all the competences with regard to tasks defined by the Conception. This fact, according to the authors, often influences missing Concepts of Family Policy at regional (NUTS 3 ) and municipal (LAU 2) levels. It could result to dependency of pro-family activities mainly on the initiatives of localities and active local people. This situation then could justify the fact that realisation of pro-family activities differs among the regions and municipalities.

Nevertheless, the main part of the document emphasises the importance of Regions (NUTS 3) and municipalities as actors of Family Policy. This fact is justified by their knowledge of the local environment (it corresponds to neo-endogenous rural development). The document states that competences with regard to Family Policy at regional (NUTS 3) and municipal (LAU 2) levels are sufficient. The Recommendation identifies two aims of local Family Policy - to create a familyfriendly environment, by the definition of a set of interconnected measures ${ }^{7}$ and to support the self-confident actions of families in order to fulfil natural family functions. The aims are supplemented by ensuing tasks - to create conditions for differentiated support of families, to engage all local actors in the realisation of pro-family measures, and to motivate families to become the subject of the implementation of Family Policy. Areas of support, including aims and specific measures, are specified in detail within the Recommendation.

According to the authors of the paper, specification of areas of support are systematically elaborated and comply with the principles of the concepts (Atkinson, 2000; Drucker, 2004) mentioned within the theoretical background of the paper.

The Recommendation mentions the actorship of Regions (NUTS 3) with regard to Family Policy within their role of representatives, conceptualisers, coordinators, organisers and informers. The roles of municipalities are defined as an implementing, including initiation, promotion and information exchange with regard to local pro-family activities and measures. As important cooperating actors, mention is made of non-governmental organisations, employers, media, educational institutions and families.

The subsequent part of the Recommendation consists of the specific procedures (both for Regions and municipalities) to launch regional and local Family Policy. The first step emphasises the need for an analysis of the local environment, using relevant indicators of local families' needs. The analysis is a basis for the setting of parameters (the second step) within the identified areas of support. This procedure is similar like the praxis of elaboration of documents in the framework of Regional Policy. The last part of the Recommendation is focused on multi-source funding of local Family Policy. Examples of the specific measures which should lead to the achievement of the above-mentioned aims are also formulated.

The authors consider that, from the perspectives of content and formal elaboration, the Recommendation could be seen as suitably inspiring for the elaboration of documents at local level. Part of the analysed local documents on Family Policy ("Development Plans of Family Policy or Conceptions of Family Policy") at municipal level used this methodological Recommendation. However, not the majority from the analysed small number of cases used this Recommendation (see below).

\footnotetext{
7 This set of measures consists of financial support for families, support of services for families, activities of a culturaleducational nature, affordable housing and the building of necessary infrastructure.
} 


\section{"Family-friendly Community" Competition}

In 2008, the Competition was launched in parallel with the above analysed Recommendation. The Competition is considered by its organisers and cooperating organisations ${ }^{8}$ as instrumental in the motivation of municipalities towards the development of pro-family activities, initiation of development of Family Policy at municipal level and promotion of pro-family atmosphere within municipalities. Thus, intentions and aims of the Competition are consistent with neo-endogenous rural development and also the tendency to strengthen the principle of subsidiarity as one of the features of reconceptualization of Welfare State.

Participation in the competition is conditional on the application of the municipality. The application form has been significantly changed during the last ten years towards its formalisation according to proposed methodology. The proposed methodology is also used for evaluation of results. Elaboration of the Plan or Conception of Family Policy of the municipality has been considered as a bonus since 2017. Financial support (municipalities of I. category - 500,000 CZK; municipalities of II. category - 900,000 CZK; municipalities of III. category $-1,100,000 \mathrm{CZK})^{9}$, which is intended for payment of non-investment costs (for the purpose of support of preventive activities contributing to the smooth functioning of families, harmonisation of family and work life and to strengthen family cohesion), remains the same during the years. Target groups are young people planning to establish of family, complete and incomplete families with children up to 18 years, families expecting the birth of a child, multigenerational families, foster families and families with specific needs (disabled members of family, families with three and more children, long-term unemployed members of family, single parents). The target groups respect the cycle of family life. Due to this reason, "Senior-friendly Community Competition" has been organised since 2017. This competition has new target groups - families with specific needs connected with care for the elderly.

However, the development of municipal participation in the Competition does not demonstrate the above-mentioned intentions and aims. High participation in the Competition at the beginning and also ensuing decrease of participation level are not surprising. However, development since the year 2013 is significantly decreasing. Thus, the use of the Competition as a measure for motivation of municipalities to systematic realisation of municipal Family Policy is questionable. The decrease of participating municipalities between the first and the last year of the Competition is to $7.3 \%$ (see Table 2).

Tab 2. Development of participation of municipalities in the Competition (2008 - 2017). Source: Non-public data obtained from internal documents of MLSA

\begin{tabular}{|l|l|c|c|}
\hline Year & $\begin{array}{l}\text { Number of } \\
\text { municipalities in } \\
\text { the Competition }\end{array}$ & $\begin{array}{l}\text { Index of } \\
\text { development (\%) }\end{array}$ & $\begin{array}{l}\text { The share of municipalities in the } \\
\text { Competition out of the total } \\
\text { number of municipalities in the } \\
\text { Czech Republic (\%) }\end{array}$ \\
\hline 2008 & 218 & 100 & 3.5 \\
\hline 2009 & 187 & 85.8 & 3.0 \\
\hline 2010 & 127 & 58.3 & 2.0 \\
\hline 2013 & 26 & 11.9 & 0.41 \\
\hline 2014 & 16 & 7.3 & 0.26 \\
\hline 2015 & 37 & 16.9 & 0.59 \\
\hline 2017 & 16 & 7.3 & 0.26 \\
\hline
\end{tabular}

Note: The results for the years 2011 and 2012 are unavailable. The Competition was not organised in 2016. Available data from the year 2018 consist only of winners of particular categories (not the number of participants).

\footnotetext{
8 The organisers are Ministry of Labour and Social Affairs, Permanent Commission on Family Issues, Equal Opportunities and Minorities; their cooperating organisations are Association of Family Centres, Network for Family and Union of Towns and Municipalities of the Czech Republic.

${ }^{9}$ Drawing funds start next year after winning the Competition.
} 
Data show similar development with regard to municipalities of up to 5,000 inhabitants (see Table 3), which are the main objects of our research. This subset consists of minimally $43.8 \%$ (in 2014 and 2017) and maximally 63.8\% (in 2010) out of the total number of participating municipalities. The share (not the absolute number) of municipalities of up to 5,000 inhabitants in the Competition increases within the first three years, then decreases until 2017 (with the exception of 2015). This means a decrease to $6.2 \%$ compared to the first year of participation. This is a higher decrease than is evident in the whole set of participating municipalities.

Tab 3. Development of participation of municipalities of up to 5,000 inhabitants in the Competition (2008-2017). Source: Non-public data obtained from internal documents of MLSA

\begin{tabular}{|c|c|l|}
\hline Year & $\begin{array}{l}\text { Number of } \\
\text { municipalities in the } \\
\text { Competition }\end{array}$ & $\begin{array}{l}\text { The share of municipalities in the Competition out } \\
\text { of the total number of municipalities in the Czech } \\
\text { Republic (\%) }\end{array}$ \\
\hline 2008 & 113 & 1.9 \\
\hline 2009 & 98 & 1.6 \\
\hline 2010 & 81 & 1.4 \\
\hline 2013 & 13 & 0.2 \\
\hline 2014 & 7 & 0.1 \\
\hline 2015 & 22 & 0.4 \\
\hline 2017 & 7 & 0.1 \\
\hline
\end{tabular}

The above-mentioned development, which shows that the Competition has not become a good measure for motivation and promotion of local Family Policy, applies especially to municipalities of up to 5,000 inhabitants. On the other hand, as an interesting finding, it could consider the fact that (with regard to our sample of municipalities up to 5,000 inhabitants which win the Competition - see Figure 1) the size of municipality and corresponding composition of the municipal council do not play an important role with regard to the efforts to systematically apply local Family Policy (6 winning municipalities of up to 1,000 inhabitants, 7 winning municipalities of 1,0012,000 inhabitants, 2 winning municipalities of 2,001-3,000 inhabitants, 3 winning municipalities of 3,001-4,000 inhabitants and 2 winning municipalities of 4,001-5,000 inhabitants). The analysis also shows that there is no close connection between repeated participation of municipalities and their success in the Competition. Two-fifths of municipalities (out of the chosen set of 20 municipalities which won the Competition - see Figure 1) repeated their participation in the Competition. Only two municipalities repeated their participation more than once. However, there is a close connection between success in the Competition and its newly established version - "Senior-friendly Community" - since its winners from the municipalities up to 5,000 inhabitants are mostly also winners of the Family-friendly Competition.

Signing up for the Competition and its evaluation have been significantly changed with regard to formalisation. This leads to desirable objectification of the evaluation. On the other hand, formalisation probably influences a loss of motivation for participation in the Competition. Formalisation means greater administrative demands for the preparation of the application and other required documents for the control of implementation. Formalisation causes more burdens especially for small rural municipalities. It is also connected with the necessary professionalisation of activities. Another negatively influencing factor is financial allocation for the Competition. The financial allocation has remained the same since 2008 , although costs of pro-family activities are increasing ${ }^{10}$.

Another fact (however more general), which could explain the significant decrease of participation in the Competition, is the increasing administrative difficulty with regard to municipal selfadministration. The smaller the municipality, the more trouble is associated in the beneficial

10 It is only possible to cover the non-investment costs supporting families at local level from the acquired subsidy. Municipalities also undertake to provide supported activities or events for at least 3 years and to cover the costs from their own budgets (within sustainability of the project). They are obliged to report on it and are also supervised on the basis of provided reports. 
division of administrative activities. Division is practically impossible when considering the smallest rural municipalities.

The analysis of documents issued for competing and winning municipalities in the Competition shows ensuing important tendency.

Methodological complexity of above mentioned documents is increasing (from instructions for winning municipalities on how to deal with the obtained subsidy, to instructions on how to increase the chances of winning the Competition). Also, emphasis on the content and formalisation of profamily activities and measures of competing municipalities is increasing. In addition, methodological complexity of the documents could inspire competing municipalities to systematically perform pro-family activities with regard to the range of performing activities and target groups. The enumeration of target groups respects both the phasing of the family cycle and the needs of specific families. The cooperative actorship of municipalities and other possible local actors with regard to implementation of local Family Policy is also emphasised.

\section{The $2^{\text {nd }}$ level of documents (Development Plans of Family Policy / Conceptions of Family Policy of Municipalities of up to 5,000 Inhabitants)}

Documents of 12 municipalities could be included in the analysis. They meet the criteria availability and structure necessary for evaluation of relevance of Recommendation for elaboration of Family Policy documents within rural municipalities in the Czech Republic. The fact that it was possible to obtain only 12 relevant documents could not been evaluated in positive manners. It does not mean that other municipalities of up to 5,000 inhabitants do not perform any activities of Family Policy. However, these activities are not performed in accordance with specific documents for Family Policy. However, on the other hand, these types of activities also meet some of the local needs.

The analysed documents differ considering their extent - the shortest consists of 5 and the longest of 30 pages of text. However, it does not mean that the extent correlates with the quality. Some briefly conceived documents are not only of good quality, but also intelligible to local inhabitants. On the other hand, documents which consist of plenty of ineffective, unnecessary and unintelligible information to local inhabitants also exist. Intelligibility of the documents is an important factor, due to the 2008 Recommendation which explicitly emphasises the motivation of families also to become subjects of the creation and realisation of Family Policy.

The structure of the analysed documents is not uniform. Five of the documents have a structure which indicates the use of the model, or they stem from the Recommendation. More than half of the analysed documents is elaborated using their own logic of their authors, which is based on local needs and priorities. It is significantly beneficial in one of these cases - the logic of elaboration of the document is based on target groups, to which is subordinated the structure of the proposed activities and measures. On the other hand, it is not significantly beneficial in another case - the text of the document describes a situation analysis within the municipality in detail. However, the proposed activities are significantly reduced. From the formal perspective, it is necessary to mention the often missing table of contents and, in some cases, also being completely identical to the model. This even entails the mechanical imitation of the format, as is evident from the analysis of the complete text of specific documents.

Appropriate use of the model clearly leads to a comprehensible content. The Introduction explains the importance of the implementation of local Family Policy. The next part consists of a description of a municipality, which is in all cases focused on settlements and demographic structure. This basic information about a municipality is often supplemented by structures according to education, employment, housing conditions and sometimes also by other aspects, which are the subject of Social Policy. Then follows the most important part of the document, from which is possible to deduce a construction of a plan of Family Policy within a municipality. This part is formulated for the vast majority of municipalities according to presumed or actually carried out activities. 
We create a typology of these activities according to their main focus according to outline stemmed from the analysis of the $1^{\text {st }}$ level of the documents:

1. Services for families (particularly childcare services and services supporting functions and family cohesion);

2. Reconciliation of work and family life (specific activities vary greatly);

3. Development of the municipality as a friendly and congenial space for family life (barrier-free access, security of living, public areas for family activities, public transport);

4. Direct support of families (material and financial gifts, discounts for families, housing support);

5. Grants and financial funds supporting pro-family organisations (consists of enumeration of possible funding);

6. Institutional, personnel and conceptual assurance of Family Policy;

7. Monitoring of family needs (including preventive components of local Family Policy);

8. Communication with families (consists of activities which encourage family engagement in municipal Family Policy within a network of local participating actors);

9. Cooperation and exchange of experience (among municipalities and other actors outside the municipality).

The first three groups could be classified as direct services, the fourth group includes indirect services. The fifth and sixth groups are focused on direct and indirect institutional support, with the aid of the accompanying activities included in the seventh group. The eighth and ninth groups represent networks of endogenous and exogenous collaborating actors.

Considering the objectives of local Family Policy, it is possible to state that:

- The vast majority of cases are focused exclusively or significantly on families with children (i.e. reproduction of mistakes from the first version of the Conception). Activities and measures are chosen for these objects of Family Policy;

- Some documents also consist of activities intended for seniors, although seniors are not explicitly mentioned;

- Only one case consists of the conscious division of family situations and follow-up activities according to phases of family development. The document accentuates support for seniors.

Despite the identified shortcomings, it is possible to conclude that the documents, analysed according to the created categories and their properties, are of relatively good quality and are elaborated with the required local engagement. Generality of the proposed aims, lack of specificity (with regard to content and time schedule) of the followed-up measures and the missing assessment of financial requirements are some of the main shortcomings. The same shortcomings were also identified with regard to the $1^{\text {st }}$ level of documents - especially within the 2005 Conception. On the other hand, it is possible to appreciate the complexity of the content of pro-family activities. The complexity is supported by knowledge of local conditions. Awareness of the significance of local Family Policy for the strengthening of local identity and community cohesion could also be positively evaluated.

\section{Discussion and Conclusion}

A shift between the versions of the Conception of Family Policy in the Czech Republic described above within the paper and also decentralisation of competences to Regions (NUTS 3) and municipalities (LAU 2) are also acknowledged and explained by Kuchařová et al. (2017). They label the period up to 2015 as "latent Family Policy". The main features of this period are the absence of a suitable model for the Conception, unwillingness of politicians to pay explicit attention to Family Policy, reluctance and inability to conceive problems in their entirety and a lack of willingness to coordinate activities across ministries. 
Various projects supporting localised pro-family activities in the Czech Republic have been realised since 2010. Workshops were held and educational leaflets focused on the establishment of local Family Policy were issued. However, as a result of above mentioned atmosphere, they did not have a broader and deeper response. As an important event to overcome this situation was the establishment of the Expert Committee for Family Policy at the Ministry of Labour and Social Affairs of the Czech Republic in 2015. The Committee is composed of the use of an interdisciplinary approach and consists of representatives of universities, public administration and praxis. On the other hand, persistent shortcomings are documented by approval of the revised version of the Conception, which took 18 months.

A similar example is also the situation with regard to enforcement of the conception of social exclusion and inclusion within the framework of the National Action Plan for Social Inclusion in the Czech Republic for the period 2004-2006. Rákoczyová (2006) evaluates its analytical part as good and useful, although the implementation part of the document is evaluated as vague and imperfectly elaborated.

Lendvai (2004) states that the above-mentioned shortcomings are typical of all post-communist states. She calls them the "performance gap" (weakness of the transformation of ideas to particular activities and their practical coordination) and "legitimacy gap" (low level of the trust of actors at the lower level of administration and self-government in central level actors). ${ }^{11}$ The analysis of both first and second levels of documents identifies a significant "performance gap" and only a gradual surmounting of it. The fact identified in our research that more than half of the municipalities with elaborated Plan or Conception of Family Policy do not use pattern referred in Recommendation from 2008 points also to "legitimacy gap".

The above-mentioned "legitimacy gap" is also identified by Kuchařová et al. (2014), using a questionnaire survey on Family Policy at regional and municipal levels. The results show the dependence between decreasing size of the municipality and the existence of an elaborated local document on Family Policy. The interest in elaboration of this document or information needed for its elaboration also significantly decreases with the decreasing number of inhabitants within a municipality. Small municipalities (according to the questionnaire survey) significantly prefer an ad hoc instead of a coordinated and systematic approach to Family Policy. ${ }^{12}$

Our results are consistent with the results of the above-mentioned survey from 2014 that (considering small municipalities) pro-family measures could be a part of other documents - most often within the development strategy of the municipality or community plan for the development of social services.

The above-mentioned discussion clarifies the reasons for the fact that, in the analysis of the second level of the documents (local documents on Family Policy), only 12 cases of municipalities up to 5,000 inhabitants could be included. Moreover, less than half of the municipalities used for the elaboration of the local document on the Family Policy pattern, which was recommended by the central level of administration.

Thus, the issue still remains whether it is meaningful to favour in the Competition municipalities with elaborated municipal plan/conception of local Family Policy, especially in the case that the objective of the Competition is to stimulate and develop local pro-family activities within rural municipalities. Participation in the Competition is significantly decreasing and the abovementioned fact does not avert it. It is used rather for the supervision from the central level of administration, while motivation of municipalities to realisation of Family Policy remains out of the interest. There is no unambiguous link between these facts (bonus for elaboration of municipal

\footnotetext{
11 The "legitimacy gap" is researched by Sirovátka et al. (2006) with regard to the implementation of the conception of social exclusion and inclusion in the public agenda of social policy. They distinguish the attitudes of actors at the lower level of administration and self-government as being from reserved to sceptical. These executive actors consider documents and recommendations at the central level as being only declarative, due to the missing instrumental measures in practice.

12 The second part of our research is focused on possible explanations of these attitudes. These may be the results of rationality (personal, time and financial needs of particular planning agenda are more difficult than possibilities of identifying and immediately solving current specific needs), the low capacity of small municipalities for projecting, or other relevant factors.
} 
plan/conception of local Family Policy and decreasing participation in the Competition). However, if any influence exists, it is rather demotivating with regard to participation in the Competition.

While it is possible that pro-family activities within municipalities up to 5,000 inhabitants are performed at a very good level, it is conditional by interest of local representatives and cooperation between other local actors.

We suppose that the necessity to elaborate various plans or conceptions for various socially oriented activities, with the same aim (collaboration to increase the quality of life) of gaining support for these activities, could be considered rather as a barrier than incentive for local development.

\section{Acknowledgement}

This article was supported by the Internal Grant Agency of FEM CULS in Prague under the Grant: "Development of Family and Community at the Intersection of Regional Family Policy", number 20161010.

Academic references

[1] Amin, A. \& Thrift, N. (1995). Institutional Issues for the European Regions - from Markets and Plans to Socioeconomics and Powers of Association. Economy and Society 24(1), 4166. DOI: $10.1080 / 03085149500000002$.

[2] Arts, W. \& Gelissen, J. (2002). Three worlds of welfare capitalism or more? A state-of-theart report. Journal of European Social Policy 12(2), 137-158. DOI: $10.1177 / 0952872002012002114$.

[3] Atkinson, R. (2000). Občanství a boj proti sociální exkluzi v kontextu reformy sociálního státu. Sociální studia 5, 43-51.

[4] Atterton, J. (2007). The Strength of Weak Ties: Social Networking by Business Owners in the Highlands and Islands of Scotland. Sociologia Ruralis 47(3), 228-245. DOI: 10.1111/j.1467-9523.2007.00435.x.

[5] Belling, V. (2005). Perspektiven der Familienpolitik nach der EU-Osterweiterung. In Lissewski, C. \& Winkler, B., eds., Internationales Jahr der Familie: 10 Jahre danach (pp. 57-63). Berlin: AGF.

[6] Blažek, J. \& Uhliř, D. (2011). Teorie regionálního rozvoje: nástin, kritika, implikace. Praha: Karolinum.

[7] Drucker, P. (2004). Fungující společnost: vybrané eseje o společenství, společnosti a politickém systému. Praha: Management Press.

[8] Esping-Andersen, G. (2009). The Incomplete Revolution: Adapting Welfare States to Women's New Roles. Cambridge: Polity Press.

[9] Frejka, T. \& Basten, S. G. (2016). Fertility and Family Policies in Central and Eastern Europe after 1990. Comparative Population Studies 41(1), 3-56. DOI: 10.12765/CPoS-2016-03en.

[10] Granovetter, M. (1985). Economic Action and Social Structure: the Problem of Embeddedness. The American Journal of Sociology 91(3), 481-510.

[11] Hudson, R. (2007). Rethinking Local and Regional Development - Implications for Radical Political Practice in Europe. European Urban and Regional Studies 14(2), 99-113. DOI: $10.1177 / 0969776407076290$.

[12] Jirková, K. (2009). Koncepce rodinné politiky a opatření iniciovaná Ministerstvem práce a sociálních věcí ČR. Demografie 51(4), 280-286. 
[13] Kocourková, J. (2009). Family Policy in EU member states. In Fialová, L., Bartoňová, D., Burcin, B., Kalibová, K., Kocourková, J., Kučera, T. \& Rychtaříková, J., eds., Population Development in the Czech Republic. Prague: SLON.

[14] Kučera, M. (2009). Pronatalitní populační politika už nestačí - Nutností se stala komplexní rodinná politika. Demografie 51(4), 274-279.

[15] Kuchařová, V., Barvíková, J., Höhne, S., Janurová, K., Nešporová, O., Paloncyová, J., Svobodová, K. \& Vidovičová, L. (2017). Zpráva o rodině. Praha: VÚPSV.

[16] Kuchařová, V., Svobodová, K., Št’astná, A. \& Podrápský, F. (2014). Rodinná politika na úrovni obcí a krajü. Principy a východiska. Praha: VúPSV.

[17] Lendvai, N. (2004). The weakest link? EU accession and enlargement: dialoguing EU and post-communist social policy. Journal of European Social Policy 14(3), 319-333. DOI: $10.1177 / 0958928704044626$.

[18] Lowe, P. (2000). The Challenges for Rural development in Europe. In Conference Proceedings of 5th European Conference on Higher Agricultural Education. Newton Abbot: University of Plymouth.

[19] Matějková, B. \& Paloncyová, J. (2004). Rodinná politika ve vybraných evropských zemích II. Praha: VÚPSV.

[20] Mlčoch, L. (2009). Rodina jako priorita: sociálně soudržná, ekonomicky konkurenceschopná. Praha: FSV UK.

[21] Mlčoch, L. (2014). Ekonomie rodiny v proměnách času, institucí a hodnot. Praha: Karolinum.

[22] Morgan, K. (2007). The learning region: Institutions, innovation and regional renewal. Regional Studies 41 (sup1), S147-S159. DOI: 10.1080/00343400701232322.

[23] Možný, I. (2006). Rodina a společnost. Praha: Sociologické nakladatelství.

[24] Munková, G. (2005). Sociální politika v evropských zemích. Praha: Karolinum.

[25] Neyer, G. (2003). Family Policies and Low Fertility in Western Europe. Journal of Population and Social Security (Population) 1 (Supplement), 46-93.

[26] Rákoczyová, M. (2006). Srovnání národních akčních plánů sociálního začleňování v zemích EU a v České republice. In Mareš, P., Rákoczyová, M. \& Sirovátka, T., eds., Sociální vyloučení a sociální začleňování v České republice jako veřejně politická agenda. Praha: CESES FSV UK.

[27] Ray, Ch. (2000). The EU LEADER programme: rural development laboratory. Sociologia Ruralis 40(2), 163-171. DOI: 10.1111/1467-9523.00138.

[28] Shucksmith, M. (2010). Disintegrated Rural Development? Neo-endogenous Rural Development, Planning and Place-Shaping in Diffused Power Contexts. Sociologia Ruralis 50(1), 1-14. DOI: 10.1111/j.1467-9523.2009.00497.x.

[29] Shucksmith, M. (2012). Class, Power an Inequality in Rural Areas: Beyond Social Exclusion?. Sociologia Ruralis 52(4), 377-397. DOI: 10.1111/j.1467-9523.2012.00570.x.

[30] Sirovátka, T., Hora, O., Horáková, M., Klimplová, L., Rákoczyová, M. \& Winkler, J. (2006). Sociální začleňování $v$ České republice: evropská a česká agenda? In Mareš, P., Rákoczyová, M. \& Sirovátka, T., eds., Sociální vyloučení a sociální začleňování v České republice jako veřejně politická agenda (55-77). Praha: CESES FSV UK.

[31] Smutek, M. (2015). Modely rodinných politik a teorie implementace ve veřejné politice. Hradec Králové: Gaudeaumus.

[32] Thévenon, O. (2011). Family Policies in OECD Countries: A Comparative Analysis. Population and Development Review 37(1), 57-87. DOI: 10.1111/j.17284457.2011.00390.x. 
[33] Ward, N., Atterton, J. H., Kim, T. Y., Lowe, P., Phillipson, J. \& Thompson, N. (2005). Universities, the knowledge economy and 'neo-endogenous rural development' [discussion paper]. University of Newcastle upon Tyne.

\section{Other sources}

[34] Barca, F. (2009). Agenda for reformed cohesion policy. Available: http://ec.europa.eu/regional_policy/archive/policy/future/pdf/report_barca_v0306.pdf, [24 Jan 2018].

[35] Belling, V. (2010). Rodinná politika: výhledy v ČR a v EU. Presentation at Conference "Modern Social System", Jihlava.

[36] Kuronen, M. (2010). Research on Families and Family Policies in Europe: State of the Art. Final Report of the FAMILYPLATFORM project. pp. 17-33.

[37] MLSA (2005). Národní koncepce rodinné politiky. Available: https://www.mpsv.cz/files/clanky/2125/koncepce_rodina.pdf, [24 Jan 2018].

[38] MLSA (2008). Rodinná politika na úrovni krajů a obcí - Metodické doporučení Ministerstva práce a sociálních věcí.

Available: https://www.mpsv.cz/files/clanky/6778/Rodinna_politika.pdf, [24 Jan 2018].

[39] MLSA (2016). Koncepce rodinné politiky.

Available: https://www.mpsv.cz/files/clanky/28437/Koncepce_rodinne_politiky_5.1.pdf, [24 Jan 2018].

[40] MLSA (2018). Family-friendly Community Competition. Available: https://www.mpsv.cz/cs/14475, [16 Dec 2018].

[41] NNLAG (2011). National strategic plan LEADER 2014+. Available: http://nsmascr.cz [11 Jan 2018].

[42] NNLAG (2012). Community-led local development in the Czech Republic. Available: http://nsmascr.cz [11 Jan 2018].

[43] Wingen, M. (1997). Směřuje Evropa ke společné rodinné politice? Lecture presented at the Civic Institute. 